\title{
STUDY ON THE LEGAL BASIS AS A MECHANISM FOR PREVENTION OF GAME FIXING IN FOOTBALL
}

\author{
K. Naydenova* \\ Department of Theory of Physical Education. National Sports Academy „Vassil Levski“, Sofia, \\ Bulgaria
}

\begin{abstract}
Match fixing on worldwide scale today is a business and a matter of profit. In this connection, the purpose of our study is to find out if there are national normative measures in place to prevent the Game fixing. The main method used in the development of the report is the study and analysis of literary sources. The results of the conducted study on the basic normative documents and regulations of the Bulgarian Football Union show the presence of a number of measures with a preventive character, which are aimed at the prevention of game fixing. Conclusions:

1. Legislative texts with subsequent sanctions are provided in the Republic of Bulgaria to prevent the fixing of football matches.

2. The Chapter of the Penal Code of 2011 includes Chapter VIII A, which is "Crimes Against Sport", and in a proven case of fixing of a sporting event, provides for a sanction of one to six years' imprisonment and a fine of one thousand to ten thousand BGN.

3. In the disciplinary rules of the BFF, a text is provided which, in the case of a confirmed game fixing, provides for the suspension of the competitor's or the official's competitions for a period of at least 18 months and a pecuniary sanction of BGN 40000 for the respective football club.
\end{abstract}

Key words: Sport, Penal Code, Act of Physical Education and Spot, Disciplinary Regulations

\section{INTRODUCTION}

Today more than ever sport is governed by business rules. Fair play is not a leading in a sport. The Principles of Baron Pierre de Coubertin's Olympism are not fundamental to the sporting struggle. In the first place is the win of the race and in a large percentage the victory is on all costs. This is dictated by the need for funding in sport. This follows the need to finance the sport. Not always the victory is for the most trained, the best performing or the worthiest of the race. In the professional sport victory depends on funding. Funding identifies preparation, recreation, participation in the competition. This applies to the most popular sport in the world - the football.

\footnotetext{
*Correspondence to: Korneliya Naydenova, Department of Theory of Physical Education. National Sports Academy ,, Vassil Levski“, Sofia, Bulgaria, Studentski grad, floor 4, office 411, phone: 00359892299811,e-mail:

knaidenova.nsa@gmail.com
}

Unfortunately, business does not always have a positive impact on sports. There is almost no sport in the world where there is no legal or illegal betting. In the world of football, there are officially possible thousands of betting options. From the selection of the final victory, the first or the last scored goal, until the minute when a certain player will be replaced. These options create the illusion of easy profit and even tempt some players in the market of match fixing.

\section{METHODOLOGY}

Based on these observations, we set ourselves as the goal of our study to find out whether there are normative measures in the country to prevent match fixing. With this goal in mind, we set out the following tasks:

1. Investigate the state of the legal betting market for football matches in the country

2. Study the contents and regulations of the main normative documents.

3. Study of the normative base of the Bulgarian Football Union. 
4. Defining the main provisions of the regulations that concern the settlement of football matches.

The object of our research is the national and private football regulations that are relevant to the prevention of the match fixing of football in the country. In this connection, the subject of the study is the influence that they have on football game. The main method used in the elaboration of the report is research and analysis of documentary sources.

\section{Exposition}

The state policy for development of sport in Bulgaria defines a structure of the sport system, according to which we can also bring out the main stakeholders related to regulating the relations in the match fixing of the outcome of football matches are: $>\quad$ Ministry of Youth and Sports

$>\quad$ Bulgarian Olympic Committee

$>\quad$ Bulgarian Football Union

$>\quad$ Football clubs

$>\quad$ Individual competitors and coaches, members of the respective clubs

\section{$>\quad$ Betting operators}

In Bulgaria there is a State Gambling Commission (2) which, on the basis of the Gambling Act regulations, licenses and regulates the relations between traders and customers on the gambling market. According to data of the Bulgarian Gambling Commission, July 2018, there are 9 licensed online merchants in Bulgaria and in the period 2013-2018 over 800 such licenses have been denied for some other reason, as part of them are presented in Table 1.

Table 1. List of websites through which bets are organized on the territory of the Republic of Bulgaria

\begin{tabular}{|llll} 
№ & Licensed online merchants & Unlicensed online merchants \\
\hline 1. & https://efbet.com/ & https://www.goldbet.com/https://www.goldbetsports.com\# \\
\hline 2. & http://toto.bg/ & http://www.bet365.net/\# \\
\hline 3. & http://www.betfair.com/ & http://www.betin.com/\# \\
\hline 4. & http://eurofootball.bg/ & http://www.morganbet.eu/\# \\
\hline 5. & https://www.7777.bg/ & http://www.betuniq.eu/\# \\
\hline 6. & $\underline{\text { http://www.bet365.com/ }}$ & http://www.planetwin365.com/\# \\
\hline 7. & http://www.winbet.bg/ & http://www.unibet.com/\# \\
\hline 8. & https://www.bwin.com/ & http://www.bet-at-home.com/\# \\
\hline 9. & http://www.efbet.bg/ & https://www.doxxbet.com/\# \\
\hline
\end{tabular}

The official policy of the Bulgarian State regarding the match fixing of the outcome of sporting events clearly and methodically follows the EU's policy on integrity in sport. Evidence in this direction only within the last year are

$>\quad$ The participation of the Minister of Sports of Bulgaria in the High Level Panel "Time to act for Europe against sport manipulations".

$>\quad$ Meeting of the Directors-General for Sport in the EU, held on 11 and 12 June this year within the framework of the Bulgarian presidency of the World of Europe, focusing on the handling of sporting competitions and the adoption of the Makoline Convention.

The participation of the Minister of Sport of Bulgaria in a working meeting on the fight against the manipulation of sports competitions, organized by the Extended Sport Partial Agreement (EPAS) of the Council of Europe and the Ministry of Sport of the Russian Federation in Moscow, before the start of the World Championship football.
The regulation of the legal relations in the sphere of sport in the Republic of Bulgaria is based on the basic legal documents - the Constitution, the Criminal Code, the Physical Education and Sports Act and all adjacent regulations. At present, investigations aimed at detecting unlawful actions related to the match fixing of sporting events are conducted in the country following a referral by the relevant national and international sports organization to the specialized prosecution in force in the country, which operates from 01.01.2012. or the Directorate-General for Combating Organized Crime.

In The Penal Code of Bulgaria in 2011 (3) is included new Chapter 8 ,a“: Crimes Against Sport, art. 307 (b-f). The relevant legislation also contains specific offences in relation to people who act as intermediaries. Penalties are up to 6 years imprisonment for active and passive corruption and up to 3 years for mediators, although they may be up to 10 years when aggravating circumstances occur - for example when offences are committed relating 
to a participant in a sports competition who is under 18 years of age; to or by a person who is a member of a managing or controlling body of a sports organisation, or involving a referee, delegate or another person undertaking their official duties or functions. The punishment is imprisonment from 3-10 years if a crime has been committed by a person acting on behalf of an organised criminal group or if the crime involves betting on the development or outcome of sporting events. Bulgaria has also amended existing provisions on illegal betting under Art. 327 Penal Code54, to ensure that the fixing of competition results by persons under the instruction of organised crime syndicates is considered as a criminal offence. Penalties of up to 10 years' imprisonment are imposed if the acts involve betting on the progress or on the outcome of a sports competition.

Currently, the Physical Education and Sport Act (4) regulates public relations related to physical education and sports in the Republic of Bulgaria. By July 2018 a number of texts for the amendment of the Physical Education and Sports Act were changed. To these changes we can comment on the removal from the Law of the aforementioned Chapter Eight - Sport Ethics. The text in it that can be interpreted in order to clarify the issue of the match fixing of sporting events is art. 27 (3) in which, as one of the activities of the Sports Federation, is to promote sport ideals and fair play rules by creating public and educational measures.

In summing up the cited text of the Physical Education and Sport Act, we have to say that no specific texts are laid down regarding the match fixing of sporting events. The lack of such texts in the Physical Education and Sport Act would logically be regulated in the various disciplinary rules of the Bulgarian Football Union.

In the Bulgarian Football Union system, the rules for determining the disciplinary offenses, the procedure for imposing the penalties provided, as well as the appeals procedures for ensuring the necessary guarantees for the protection of the rights and interests of clubs, footballers and officials in the meetings for the championships football tournaments are governed by the Disciplinary Code (1). The Bulgarian Football Union Disciplinary Code is mandatory for all football clubs, footballers and officials. Unlike the above-mentioned normative documents, there are texts that regulate the match fixing of sporting events.
The wording in the disciplinary regulation of the problem at issue is: "uncontrolled influence of the development of the result or of the final result of a football match".

At the beginning of the Disciplinary Code, there are 3 articulars $-4,7$ and 8 , which we can define as introductory in the problem of match fixing and which ensure synchronization with the main documents of UEFA and FIFA. The texts in them are as follows:

Art. 4. Clubs, Coaches, Athletes, Leaders and Club Members are required to abide by the principles of the Code of Ethics, Supporter Charter, Loyalty, Honesty, Integrity, Goodwill, Correct Behavior, and Sporting Behavior.

Art. 7. (1) A violation within the meaning of the Regulations is an act or omission which violates the rules and / or rules established by the Articles of Association of the BFU, the regulations, regulations and decisions adopted by the BF IC or by FIFA or UEFA in the provided from the rule cases.

Art. 8. Infringements within the meaning of these Rules are:

- violation of legal regulations in the Republic of Bulgaria and the documents of FIFA and UEFA.

The document examined also contains Art. 46, which is entirely aimed at counteracting match fixing. It covers a total of 7 points, each of which examines the penalties of the persons involved in the match fixing.

Art. 46. (1) Where the non-injurious influence of the development of the result or of the final result of a football match is established, the following penalties shall be imposed:

1. a football player - suspension of the competitor's rights during the term of the player's sentence (respectively for the period of administrative penalty imposed by administrative penalty), but not less than 18 (eighteen) months;

2. to an official, an official of the FC, a medical person, a coach or a manager - a ban on the performance of functions for the term of the sentence (respectively, for the period of administrative penalty imposed in administrative-criminal order), but not less than 18 (eighteen) months;

3. the football club to which the persons under item 1 or item 2 belong - a pecuniary sanction of 40000 (forty thousand) BGN and the transfer of the team to a lower level (the next in descending order) for the next sporting - a competitive year without the right to complete 
his participation in the current sporting competition.

(2) In cases where pre-trial proceedings for actions under para. 1, the Disciplinary Commission suspends the rights of the persons under par. 1, item 1 or 2 .

(5) Where a player, official, official of the FC, medical officer, coach or manager is established to participate in betting or other related to the participation of a Bulgarian club in the championships and tournaments organized by BFU or BPFL or in international meetings and tournaments, a suspension of competitive rights, respectively a ban on the performance of functions for a term of 6 (six) months and a fine of 5000 (five thousand) BGN shall be imposed.

(6) When the UEFA receives a UEFA official notification within the sporting competition year of serious doubts about participation in the Championships, the Bulgarian Cup, the Super Cup or other, with a preliminary agreed result, the team involved shall be warned or penalizes as follows:

a) At first formal notification - The Integrity Officer of the Bulgarian Football Union (BFU) draws up a warning protocol, signed by the persons involved, informing UEFA about this;

(b) on second formal notice - reprimand;

c) in the third notification - reprimand and property sanction amounting to 5000 (five thousand) BGN;

(d) on the fourth and subsequent notice - the property sanction under b. "In" doubles, triggers, and so on.

(f) Where it is established that information of a sporting and technical nature of a confidential nature has been disclosed by persons related to national teams or FCF members to third parties in order to influence the development or outcome of a football match or to committing other crimes of a general nature involving the national teams or FC members of the BFU, the penalties under para. 1 , items 1 and 2 .
NAYDENOVA $K$.

(7) In the event of significant public-reluctant doubts and a proposal by the Ethics and Fair Play Commission, the DK may impose a penalty on moving the team to a lower group or level (the next in descending order) for the next sporting competition year the right to complete his participation in the current sporting competition year.

Looking at and analysing the main normative documents that are relevant to the organization of football matches, we can draw the following conclusions:

1. Legislative texts with subsequent sanctions are provided in the Republic of Bulgaria to prevent the fixing of football matches.

2. The Chapter of the Penal Code of 2011 includes Chapter VIII A, which is "Crimes Against Sport", and in a proven case of fixing of a sporting event, provides for a sanction of one to six years' imprisonment and a fine of one thousand to ten thousand BGN.

3. In the disciplinary rules of the BFF, a text is provided which, in the case of a confirmed game fixing, provides for the suspension of the competitor's or the official's competitions for a period of at least 18 months and a pecuniary sanction of BGN 40000 for the respective football club.

\section{REFERENCES}

1. Bulgarian Football Union - Disciplinary Regulation (2018) (Дисциплинарен правилник). Download-URL: https://bfunion.bg/uploads/2018

2. Bulgarian Gambling Commission - Register of the Bulgarian Gambling Commission About Licensed Online Merchants in Bulgaria. Download-URL: http://eportal.dkh.minfin.bg/Register, 2018

3. Bulgarian Penal Code. Download-URL: https://www.lex.bg/laws/ldoc/1589654529

4. Bulgarian Act of Physical Education and Sport Download-URL: ,https://www.lex.bg/laws/ldoc/1589654529 